\title{
PENERAPAN METODE LATIHAN INTERVAL DALAM MENINGKATKAN KECEPATAN RENANG GAYA BEBAS 50 METER
}

\author{
Oleh: Ujang Rohman ${ }^{1^{*}}$ \\ ${ }^{1}$ Program Studi Pendidikan Jasmani, Fakultas Kegurun dan Ilmu Pendidikan \\ Universitas PGRI Adi Buana Surabaya \\ Email : ujang_roh64@unipasby.ac.id
}

\begin{abstract}
The purpose of this study is to obtain a picture of the effect of interval training on the freestyle swimming speed. Limitation of this study focused on the effect of interval training on the speed of the 50m freestyle at the UKM Olahraga Renang Universitas PGRI Adibuana Surabaya. This study uses pre-experimental design using initial test followed by the provision of a new interval workout then do the final test. The population in this study is the swimmer who joined in the UKM Olahraga Renang Universitas PGRI Adibuana Surabaya, amounting to 30 players and the same sample with the population that is 30 players. The design is an experiment involving two groups: treatment group and the untreated group using the pre test and post test. Test results of the control group pre-test average of 73.02, the average post test 58.34. t-test results greater than t-table (3.84> 2.14). Comparison between pre test and post test results in the control group no significant differences, only 20:11\% increase the test results. While the results of experimental tests concluded that the average pre test 58.53, the average post-test 85.85 . $\mathrm{t}$ test results greater than $\mathrm{t}$-table $(2.01<2.14)$. Comparison between pre test and post test results on the experimental group were no significant differences. The magnitude of the effect may improve the outcome kecepaan freestyle as much as $47 \%$. Comparison test between the control group with experimental group obtained tcount is 4.558, t-count is more than t-table (4.55> 2.04). Can be said comparison between the experimental groups with control groups and the results were no significant differences could be said after being given the treatment has the ability to swim freestyle better.
\end{abstract}

Keywords: Interval training, Swimming speed freestyle

\section{A. PENDAHULUAN}

Renang adalah cabang olahraga air (aquatik) yang berupaya menggerakkan seluruh bagian tubuh ke atas permukaan air. Menurur Budingsih (2010) Renang adalah salah satu olahraga air yang dilakukan dengan menggerakkan badan di air, seperti menggunakan kaki dan tangan sehingga badan terapung dipermukaan air.Renang terdiri dari empat gaya yaitu gaya bebas, gaya punggung, gaya katak dan gaya kupu-kupu. Diantara keempat gaya renang tersebut, diantaranya renang gaya bebas. Renang gaya bebas adalah salah satu gerakan renang yang dilakukan dengan sikap badan telungkup dan kedua kaki digerakkan secara linier. Karakteristik renang gaya bebas adalah seluruh anggota badan berada dalam satu garis lurus, dengan menggerakkan kedua lengan berada pada permukaan air. Pada renang gaya 
Penerapan Metode Latihan Interval Dalam Meningkatkan Kecepatan Renang Gaya Bebas 50 Meter Oleh: Ujang Rohman

bebas yang dirasakan cukup sulit gerakannya yaitu pada saat pengambilan nafas dibandingkan gaya renang lainnya. Pada renang gaya dada dan gaya kupu-kupu, bernafas bisa dilakukan cukup mudah karena kepala seluruhnya berada diatas permukaan air. Bernafas dalam gaya punggung juga tidak sulit karena kepala dan tubuh menghadap dengan bebas ke arah atas. Sedangkan pengambilan nafas pada renang gaya bebas,kepala tidak boleh sepenuhnya menyembul dari permukaan air. Inilah yang menjadikan bernafas dalam gaya bebas terasa cukup sulit sehingga perlu adanya koordinasi yang menyeluruh saat melakukan gerakan renang gaya bebas. Gerakan menyeluruh saat melakukan renang gaya bebas perlu dikembangkan dalam bentuk metode latihan yang sesuai dengan karakteristiknya. Atas dasar tersebut maka perlu adanya penelitian yang mengkaji mengenai kemampuan kecepatan perenang yang memiliki daya tahan saat aktivitas geraknya. Diantara beberapa metode latihan, salah satu metode latihan yang dapat mengembangkan kemampuan kondisi fisik perenang sesuai dengan karakteristik renang gaya bebas adalah metode latihan interval(interval training).

Metode latihan interval merupakan salah satu metode latihan untuk melatih kemampuan kondisi fisik.Latihan interval dilakukan dengan menggunakan waktu istirahat diantara rangkaian kegiatan yang harus dilakukan, dengan selang istirahat. Latihan itu merupakan bentuk latihan yang bertujuan untuk membina dan mengembangkan komponen kondisi fisik yang terdiri dari unsur kekuatan, kecepatan, daya tahan dan stamina. Latihan interval salah satu latihan yang mempunyai pengaruh baik terutama pada paru-paru, jantung dan peredaran darah. Latihan interval adalah metode latihan yang sering digunakan oleh para pelatih hampir di semua cabang olahraga diantaranya pada olahraga renang, lari dan bersepeda.Latihan interval adalah suatu sistem latihan yang terdapat pengulanganpengulangan dan diselingi dengan waktu istirahat tertentu di setiap pengulangan.MenurutSungkowo, Rahayu dan Budianto (2015), metode latihan interval 1:1 dimana waktu kerja sebanding dengan waktu istirahat sehingga metode latihan 1:1 memberikan kemudahan bagi para atlet untuk melakukan latihan yang sebanding dengan waktu kerja dan waktu istirahat dimana sistem energi yang digunakan adalah ATP-PC + laktat (20-45 detik) sehingga cocok digunakan kecepatan renang 50 meter.Sedangkanmenurut Zabdillah, Sugiyanto dan Januarto (2017), interval training berpengaruh secara signifikan terhadap peningkatan VO2 maks. VO2 maks adalah jumlah maksimal oksigen yang dapat dikonsumsi selama aktivitas fisik yang intens sampai akhirnya terjadi kelelahan. Jadi dapat dikatakan bahwa metode latihan interval merupakan metode yang tepat dalam meningkatkan kondisi fisik olahragawan. Latihan interval lebih 
Penerapan Metode Latihan Interval Dalam Meningkatkan Kecepatan Renang Gaya Bebas 50 Meter Oleh: Ujang Rohman

mengutamakan pemberian waktu interval (istirahat) pada saat antar set, dengan bentuk aktivitas antara lain dapat dengan cara berlari dan atau berenang (Sukadiyanto, 2011).

Program latihan interval untuk perenang jarak $50 \mathrm{~m}$ sangat diperlukan, sebab selama ini metode pelatihan untuk nomor tersebut membutuhkan waktu latihan yang cukup lama dan membosankan. Fenomena pelatihan tersebut menyebabkan atlet lebih menekuni nomor jarak pendek, sehingga jumlah atlet untuk renang jarak jauh lebih sedikit, untuk itu dalam pelatihan renang khususnya jarak $50 \mathrm{~m}$ diperlukan inovasi pemberian dosis latihan yang dapat mengatasi masalah diatas. Dalam olahraga renangjumlah energi yang digunakan juga tergantung pada keterampilan perenang menguasai gerakan. Seorang pemula akan menggunakan energi lima kali lebih banyak dari pada seorang perenang yang sudah berpengalaman atau telah menguasai gerakan berenang. Dengan demikian peningkatan efisiensi energi dalam berenang dengan gerakan yang benar atau menguasai teknik yang bagus taraf pengeluaran energi hanya150 kalori / menit atau 14,07 tenaga kuda, sehingga dapat dikatakan bahwa olahraga renang bukanlah olahraga yang ringan, terutama bagi perenang pemula.

Mengingat pentingnya gerakan berenang, terutama pada renang gaya bebas,maka seorang perenang perlu dilatih kecepatan geraknya secara khusus dan terus menerus. Untuk meningkatkan kecepatan maksimal banyak metode latihan yang digunakan, salah satu metode latihan yang digunakan adalah metode latihan interval. Mengacu pada hal tersebut dalam penelitian ini akan diteliti mengenai penerapan metode latihan interval pengaruhnya pada kecepatan renang gaya bebas $50 \mathrm{~m}$. Permasalahan yang diangkat dalam penelitian ini adalahapakah penerapan model latihan interval dapat meningkatkan kecepatan renang gayabebas $50 \mathrm{~m}$. Sedangkan tujuan dalam penelitian ini untuk memngetahui dan membuktikanpenerapan metodelatihan interval pengaruhnya dalam meningkatkan kecepatan renang gaya bebas $50 \mathrm{~m}$.Sesuai dengan permasalahan tersebut, urgensi penelitianini dapat direkomendasikan sebagai acuan dan pedoman bagi para pelatih renang dalam melatih kecepatan renang gaya bebas melalui proses penerapan metode latihan interval.

\section{B. METODE}

Metode yang digunakan dalam penelitian ini adalah metode eksperimental semu yang melibatkan 2 kelompok yaitu kelompok perlakuan dan kelompok yang tidak dapat perlakuan (kontrol). Desain penelitian menggunakan pre testand post testcontrol group.

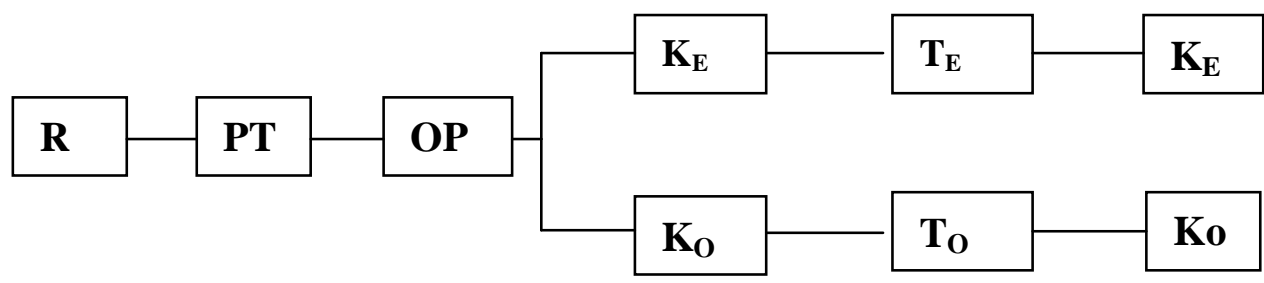


Penerapan Metode Latihan Interval Dalam Meningkatkan Kecepatan Renang Gaya Bebas

50 Meter

Oleh: Ujang Rohman

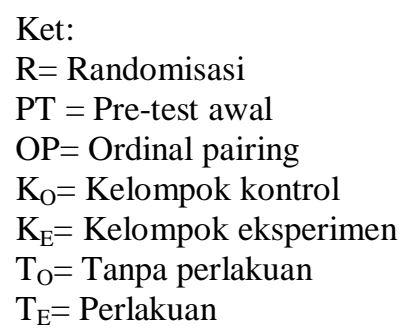

Desain pre test and post test control group, setelah tes awal dan menyeimbangkan diantara kelompok, maka dilakukan periode pasangan yang berdasarkan data hasil tes. Subyek dibagi menjadi 2 kelompok yaitu kelompok eksperimen $\left(\mathrm{K}_{\mathrm{E}}\right)$ yang mendapatkan latihan interval, sedangkan kelompok kontrol $\left(\mathrm{K}_{\mathrm{O}}\right)$ tidak mendapatkan latihan interval (variabel control). Populasi adalah keseluruhan subyek yang diteliti dan mempunyai karateristik yang sama. Populasi dalam penelitian ini adalah mahasiswa yang mengikuti kegiatan UKM Olahraga Renang Universitas PGRI Adi Buana Surabayayang berjumlah 45 perenang. Sampel penelitian sebanyak 30 diambil secara random dari jumlah populasi yang ada di wilayah penelitian yang bersifat homogen. Alat pengumpulan data menggunakan instrumen tes kecepatan renang gaya bebas50 meter. Teknik analisis data melalui tahapan uji normalitas dan uji homogenitas data. Setelah data dinyatakan normal dan homogen selanjutnya dilakukan uji-t menggunakan analisis Pairedsample t-test untuk membandingkan nilai rata-rata dari variabel antara sebelum (pre-test) dan sesudah (post-test) perlakuan dan uji-t menggunakan Independent sample t-test untu membandingkan rata-rata kedua kelompok variabel memiliki nilai rata-rata sama atau tidak secara signifikan.

\section{HASIL DAN PEMBAHASAN}

Berdasarkan hasil analisis uji normalaitas data kedua kelompok latihan diperoleh hasil pada tabel 1 berikut.

Tabel 1.Normalitas Data

\begin{tabular}{clrcc}
\hline \multirow{2}{*}{ No. } & \multicolumn{2}{c}{ Variabel } & \multicolumn{2}{c}{ Uji Normalitas - Chi Square } \\
\cline { 2 - 5 } & \multicolumn{1}{c}{ Bebas $(\mathrm{X})$} & Terikat $(\mathrm{Y})$ & $\chi_{\text {Hitung }}^{2}$ & $\chi_{\text {Sig.0.05 }}^{2}$ \\
\hline 1 & Eksperimen $\left(\mathrm{K}_{\mathrm{E}}\right)$ & Kecepatan Renang & 7.45 & \multirow{2}{*}{9.49} \\
2 & Kontrol $\left(\mathrm{K}_{\mathrm{O}}\right)$ & & 5.40 & \\
\hline
\end{tabular}

Data pada tabel 1 diperoleh nilai chi square $\left(\chi^{2}\right)$ hitung sebesar 7.45 sedangkan nilai $\chi^{2}$ tabel dengan derajat kebebasan $(\mathrm{df})=14$ dan tarap keselahan $(\alpha)=0.05$ di dapatkan nilai chi kuadrat tabel $\left[\chi^{2}\right.$ Sig.(0.05)] sebesar 9.49 berarti nilai $\chi^{2}$ hitung nilai lebih kecil daripada 
Penerapan Metode Latihan Interval Dalam Meningkatkan Kecepatan Renang Gaya Bebas 50 Meter Oleh: Ujang Rohman

nilai $\chi^{2}$ tabel $(7,45<9,49)$ artinya distribusi data tes kelompok eksperimen dinyatakan normal. Sedangkan data untuk kelompok kontrol diperoleh nilai chi square $\left(\chi^{2}\right)$ hitung sebesar5,40 sedangkan nilai $\chi^{2}$ tabel dengan derajat kebebasan $(\mathrm{df})=14$ dan tarap kesalahan $(\alpha)=0.05$ di dapatkan nilai chi kuadrat tabel [ $\chi^{2}$ sig.(0.05)] sebesar 9.49 berarti nilai $\chi^{2}$ hitung nilai lebih kecil daripada nilai $\chi^{2}$ tabel $(5,40<9,49)$ artinya distribusi data tes kelompok kontrol dinyatakan normal.

Hasil analisis uji homogenitas data untuk kelompok eksperimen dan kontrol pada tabel 2 berikut.

Tabel 2.Homogenitas Data

\begin{tabular}{cllcc}
\hline \multirow{2}{*}{ No. } & \multicolumn{2}{c}{ Variabel } & Uji Homogenitas - Barlett-Box F \\
\cline { 2 - 5 } & \multicolumn{1}{c}{ Bebas $(\mathrm{X})$} & Terikat $(\mathrm{Y})$ & $\mathrm{F}_{\text {Hitung }}$ & $\mathrm{F}_{\text {Sig. } .05}$ \\
\hline 1 & Eksperimen $\left(\mathrm{K}_{\mathrm{E}}\right)$ & Kecepatan Renang & 1.83 & 2.48 \\
2 & Kontrol $\left(\mathrm{K}_{\mathrm{O}}\right)$ & & 1.91 & \\
\hline
\end{tabular}

Data pada tabel 2 dapat diketahui hasil uji homogenitas menggunakan Barlett-BoxF kesamaan dua varians diperoleh nilai F-hitung kelompok eksperimen $\left(\mathrm{K}_{\mathrm{E}}\right)$ sebesar 1,83 dan kelompok kontrol $\left(\mathrm{K}_{\mathrm{O}}\right)$, dimana nilaik F-tabel dengan derajat kebebasan $(\mathrm{dk})=\mathrm{n} 1-1 ; \mathrm{n} 2$ - 1 ) dan taraf kesalahan $(\alpha)=0.05$ sebesar 2.48. Sesuai kriteria berartiF-hitungkelompok eksperimen $\left(\mathrm{K}_{\mathrm{E}}\right)$ lebih kecil daripada F-tabel $(1,83<2,48)$ danF-hitung kelompok kontrollebih kecil daripada F-tabel $(1.91<2,48)$ artinya data kelompok eksperimen dan kontrol dinyatakan homogen.

Setelah data dinyatakan normal dan homogen, selanjutnya dilakukan dianalisis ujitmenggunakan analisis paired-sample t-test bertujuan untuk melakukan pengujian terhadap satu variabel yang mendapatkan perlakuan (treatment) kemudian membandingkan nilai rata-rata dari variabel tersebut antara sebelum (pre-test) dan sesudah (post-test) perlakuan.

Hasil data hasil analisis paired-sample t-test renang gaya bebas 50 meter pada kelompok eksperimen dan kelompok kontrol pada tabel 3berikut.

Tabel 3.Data Paired-sample t-testVariabel

\begin{tabular}{clccc}
\hline \multirow{2}{*}{ No. } & \multicolumn{2}{c}{ Variabel } & \multicolumn{2}{c}{ Paired-sample t-test } \\
\cline { 2 - 5 } & \multicolumn{1}{c}{ Bebas $(\mathrm{X})$} & Terikat $(\mathrm{Y})$ & $\mathrm{t}_{\text {hitung }}$ & $\mathrm{t}_{\text {Sig.0.05 }}$ \\
\hline 1 & Eksperimen $\left(\mathrm{K}_{\mathrm{E}}\right)$ & Kecepatan Renang & 3.84 & \multirow{2}{*}{2.14} \\
2 & Kontrol $\left(\mathrm{K}_{\mathrm{O}}\right)$ & & 2.01 & \\
\hline
\end{tabular}


Penerapan Metode Latihan Interval Dalam Meningkatkan Kecepatan Renang Gaya Bebas 50 Meter Oleh: Ujang Rohman

Data pada tabel 3 diperoleh nilai t-hitung kelompok eksperimen $\left(\mathrm{K}_{\mathrm{E}}\right)$ sebesar3,84 sedangkan nilai t-tabel dengan derajat kebebasan $(\mathrm{df})=14$ dan tarap kesalahan $(\alpha)=0.05$ di dapatkan nilai t-tabel[t $\mathrm{t}_{\text {Sig.(0.05)] }}$ sebesar 2,14 berarti nilai t-hitung nilai lebih besar daripada nilai ttabel ( $3.84>2.14$ ), artinya penerapan metode latihan interval berpengaruh dalam meningkatkan kecepatan renang gaya bebas pada kelompok eksperimen $\left(\mathrm{K}_{\mathrm{E}}\right)$. Sedangkan data untuk kelompok kontrol $\left(\mathrm{K}_{\mathrm{O}}\right)$ diperoleh nilai t-hitung sebesar2.01 sedangkan nilai t-tabel dengan derajat kebebasan $(\mathrm{df})=14$ dan tarap kesalahan $(\alpha)=0.05$ di dapatkan nilai t-tabel [t Sig.(0.05)] sebesar 2.14 berarti nilai t-hitung nilai lebih kecil daripada nilai t-tabel $(2.01<2.14)$,artinya penerapan metode latihan interval tidak ada pengaruhnya dalam meningkatkan kecepatan renang gaya bebaskelompok kontrol $\left(\mathrm{K}_{\mathrm{O}}\right)$.

Dari hasil analisis tersebut di atas, diperoleh data bahwa variabel yang diberi perlakuan metode latihan interval mempunyai pengaruh terhadap kecepatan renang gaya bebas siswa $50 \mathrm{~m}$. Pengaruh tersebut sebagai akibat dari latihan yang diberikan secara interval, yang menunjukkan perubahan peningkatan sebelum diberikan perlakukan dan sesudah diberikan perlakukan pada kelompok eksperimen yang mencapai peningkatan secara signifikan. Peningkatan yang signifikan sebagai efek dari perlakuan yang dilakukan secara sistematis, berulang-ulang dan dilakukan dalam jangka waktu yang cukup lama. Efek ini merupakan respon fisiologi tubuh yang disebabkan oleh beban dalam bentuk latihan dengan diselingi interval berupa masa istirahat. Respon fisiologis pada tubuh dikarenakan adanya perubahan fungsi tubuh yang besifat menetap sebagi akibat dari latihan yang diberikan. Menurut Wiarto (2013), perubahan tubuh sebagai akibat dari latihan akan terjadi pada sistem kardiovaskuler antara lain meningkatnya ukuran jantung, menurunnya denyut jantung, meningkatnya curah jantung, meningkatnya volume darah dan terjadinya hypertrophy otot. Hasil penelitian Sri Wahyuniati (2011), latihan interval mampu mempengaruhi adanya perubahan kemampuan fisik (daya tahan aerobik/VO2 maks) sebesar 0,589 kg bb m/dtk. Selain itu menurut Graef dkk (2009) menjelaskan bahwa High Intensity Interval Training (HIIT) atau latihan interval dengan intensitas tinggi efektif dalam meningkatkan VO2 maks sebesar 9\%. Metode latihan interval intensif cukup memberikan sumbangan yangefektif terhadap peningkatan kemampuan VO2 Max, begitu juga dengan metode latihan interval ekstensif cukup memberikan sumbangan yang efektif terhadap peningkatan kemampuan VO2 Max (Suhdy, 2018)

Beberapa konsep tersebut menggambarkan bahwa dengan meningkatnya daya tahan dan VO2 maks seseorang akan menunjang kemampuan motorik dalam melakukan aktivitas fisik. Salah satu kemampuan motorik tersebut diantaranya adalah komponen kecepatan. 
Penerapan Metode Latihan Interval Dalam Meningkatkan Kecepatan Renang Gaya Bebas 50 Meter Oleh: Ujang Rohman

Karena menurut Sungkowo, Rahayu dan Budianto,(2015), metode latihan interval 1:1 dimana waktu kerja sebanding dengan waktu istirahat sehingga metode latihan 1:1 memberikan kemudahan bagi para atlet untuk melakukan latihan yang sebanding dengan waktu kerja dan waktu istirahat dimana sistem energi yang digunakan adalah ATP-PC + laktat (20-45 detik) sehingga cocok digunakan kecepatan renang 50 meter. Selain itu menurut Ihsan, Mentara dan Kamarudin (2017), penerapan latihan menggunakan latihan interval training mempunyai pengaruh yang signifikan terhadap peningkatan kecepatan.

Untuk mengetahui apakah kedua kelompok variabel $\left(\mathrm{K}_{\mathrm{E}}\right.$ dan $\left.\mathrm{K}_{\mathrm{O}}\right)$ yang tidak berhubungan memiliki rata-rata yang berbeda, maka uji-t yang digunakan melalui analisis independent sample t-test yang bertujuan membandingkan rata-rata kedua kelompok variabel mempunyai nilai rata-rata sama atau ridak secara signifikan.

Hasil perbedaan rata-rata tes renang gaya bebas 50 meter pada kelompok eksperimen $\left(\mathrm{K}_{\mathrm{E}}\right)$ dan kelompok kontrol $\left(\mathrm{K}_{\mathrm{O}}\right)$ pada tabel 4 berikut.

Tabel 4.Data Independent sample t-test variabel

\begin{tabular}{cccc}
\hline \multirow{2}{*}{$\mathrm{N}$} & Variabel & \multicolumn{2}{c}{ Independent sample t-test } \\
\cline { 3 - 4 } & & $\mathrm{t}_{\text {Hitung }}$ & $\mathrm{t}_{\text {Sig.0.05 }}$ \\
\hline 30 & Kecepatan Renang & 4.55 & 2.04 \\
\hline
\end{tabular}

Data pada tabel 4 diperoleh nilai perbedaan rata-rata t-hitung kelompok eksperimen $\left(\mathrm{K}_{\mathrm{E}}\right)$ dan kelompok kontrol $\left(\mathrm{K}_{\mathrm{O}}\right)$ sebesar4.55sedangkan nilai t-tabel dengan derajat kebebasan $(\mathrm{df})=28$ dan tarap kesalahan $(\alpha)=0.05$ di dapatkan nilai t-tabel [t $\mathrm{Sig} \cdot(0.05)$ ] sebesar 2,04 berarti nilai t-hitung nilai lebih besardaripada nilai t-tabel (4.55>2.04), artinya ada perbedaan pengaruh penerapan metode latihan interval dalam meningkatkan kecepatan renang gaya bebas antara kelompok eksperimen $\left(\mathrm{K}_{\mathrm{E}}\right)$ dengan kelompok kontrol $\left(\mathrm{K}_{\mathrm{O}}\right)$.

Hasil analisis yang menunjukkan adanya perbedaan pengaruh penerapan metode latihan interval pada kelompok eksperimen dengan kelompok kontrol dalam meningkatkan kecepatan renang gaya bebas disebabkan efek dari kelompok eksperimen yang diberi perlakuan mempunyai kemampuan yang lebih meningkat dibandingkan kelompok kontrol yang tidak diberi perlakukan. Efek latihan ini menurut Budiwanto (2012), menngakibatkan pengaruh terhadap sistem pernafasan sangat progresif, karena setelah latihan 4-6 minggu, efisiensi maksimum telah dapat dicapai. Hal ini disebabkan karena meningkatnya fungsi neuromuscular, yang menyebabkan pengambilan $\mathrm{O} 2$ dan pelepasan $\mathrm{CO} 2$ menjadi lebih baik. Selain itu karakteristik latihan intervalsuatu sistem latihan yang terdapat pengulangan-pengulangan dan diselingi dengan waktu istirahat tertentu di setiap 
Penerapan Metode Latihan Interval Dalam Meningkatkan Kecepatan Renang Gaya Bebas 50 Meter Oleh: Ujang Rohman

pengulangan. Adanya pengulangan disetiap aktivitas fisik latihan interval akan memudahkan seseorang melakukan latihan yang sebanding dengan waktu kerja dan waktu istirahat dimana sistem energi yang digunakan adalah ATP-PC + laktat (20-45 detik) sehingga cocok digunakan kecepatan renang 50 meter (Sungkowo, Rahayu danBudianto, 2015).

Dengan demikian dapat dikatakan bahwa efek perlakuan berupa metode latihan interval merupakan adaptasi dan respon fisiologi dari latihan yang dilakukan secara sistematis, berulang-ulang dan dilakukan dalam jangka waktu yang cukup lama. Adaptasi fisiologis pada tubuh dikarenakan adanya perubahan fungsi tubuh yang bersifat menetap sebagai akibat dari latihan yang diberikan. Perubahan tersebut adalah respon fisiologis dari sistem kardiovaskular, respirasi dan muskuluskeleton.

\section{SIMPULAN}

Berdasar pada pembahasan tersebut di atas, dapat disimpulkan bahwa: (1) penerapan metode latihan interval dapat meningkatkan kecepatan renang gaya gaya bebas 50 meter yang diterapkan pada atlet Unit Kegiatan Mahasiswa (UKM) cabang olahraga renang di Universitas PGRI Adi Buana Surabaya. (2) Uji perbandingan antara kelompok eksperimen (KE) dengan kelompok kontrol (KO) ternyata hasilnya ada perbedaan yang signifikan pengaruh penerapan metode latihan interval traing dalam peningkatan kecepatan renang gaya gaya bebas 50 meter pada atlet Unit Kegiatan Mahasiswa (UKM) cabang olahraga renang di Universitas PGRI Adi Buana Surabaya.

Rumuskan temuan hasil penelitian ini adalahpenerapan metode latihan interval dapat meningkatkan kecepatan renang gaya gaya bebas 50 meter dan ada perbedaan yang signifikan hasil metode latihan interval antara yang diberi perlakukan dengan yang tidak diberi perlakukan.

\section{DAFTAR PUSTAKA}

Budiningsih, Annayanti. 2010. Berenang Gaya Bebas. Kudus: Pura Barutama

Budiwanto, S. 2012. Metodologi Kepelatihan Olahraga. Fakultas Ilmu Keolahragaan UM Malang: UM Press.

Graef, Jennifer L., Smith, Abbie E., Kendall, Kristina L., Fukuda, David A. \& Stout, Jeffrey R. 2009. The Effects of Four Weeks of Creatine Supplementation and High 
Intensity Interval Training on Cardiorespiratory Fitness: A Randomized Controlled Trail. Journal of the International Society of Sport Nutrition. 6 (8); 1-7

Muhammad Suhdy.2018.Pengaruh Metode Latihan Intervalintensifdan Interval Ekstensifterhadap Peningkatan Vo2 max. Jurnal Gelanggang Olahraga. 1 (2); 1-10

Mohammad Zulmi Fairuz Zabdillah, Sugiyanto dan Oni Bagus Januarto. 2017. Pengaruh Interval Training Terhadap Peningkatan Vo2 Maks Peserta Ekstrakurikuler Futsal. Jurnal Gelanggang Pendidikan Jasmani (GPJI). 1 (2); 229-237

Nur Ihsan, Hendrik Mentara, Kamarudin. 2017. Pengaruh Latihan Interval Training Terhadap Kecepatan Dalam Permainan Futsal Pada Atlet Orinity. Journal Sport Sciences and Physical Education. VI (1); 54-65

Sukadiyanto., 2011. Pengantar Teori dan Metodologi Melatih Fisik., Penerbit Fakultas Ilmu Keolahragaan, UNY Yogyakarta.

Sungkowo, Kaswarganti Rahayu, Kumbul Slamet Budianto. 2015. Pengaruh Latihan Interval dan Kapasitas Vital Paru Terhadap Kecepatan Renang 50 Meter Gaya Crawl. Jurnal Media Ilmu Keolahragaan Indonesia 5 (1); 24-29

Sriwahyuniati, C. Fajar. 2011. Pengaruh Latihan Interval Training Terhadap Perubahan Kemampuan Fisik Atlit Bola Voli Yunior. Skripsi tidak diterbitkan. UNY Yogyakarta: Fakultas Ilmu Keolahragaan.

Wiarto, Giri. 2013. Fisiologi dan Olahraga. Yogyakarta: GRAHA ILMU.

Biodata Penulis :

Nama : Ujang Rohman

Kantor : Universitas PGRI Adi Buana Surabaya 